ljtihad, Jurnal Wacana Hukum Islam dan Kemanusiaan

Vol. 16, No. 2 (2016), pp. 197-216, doi : 10.18326/ijtihad.v16i2.197-216

\title{
Telaah kritis model screening saham syariah menuju pasar tunggal ASEAN
}

\author{
M. Ardiansyah, Ibnu Qizam, dan Abdul Qoyum \\ Fakultas Ekonomi dan Bisnis Islam UIN SunanKalijaga Yogyakarta \\ E-mail:misnen_ardy@yahoo.com; qrami68@gmail.com;agus.qoyum@yahoo.com
}

DOI: 10.18326/ijtibad.v16i2.197-216

Shariah stocks is one of the financial sectors that experienced with most significant growth in recent years. the most important issue in Shariah stock is Stock screening mechanism. The aim of this study is to examine the screening models of Shariah stocks in ASEAN countries. This study is very crucial especially in the era of ASEAN economic community (AEC). In addition, this study aims to examine some of the factors that contribute to the differences in screening models applied in five ASEAN countries. By using descriptive method and literature studies approach, this study found a few things. Firstly, there are various models of Shariah stock screening in Indonesia, Malaysia, Singapore, Thailand and Philippines. In this context, the model screening in ASEAN countries have two tendencies, namely; for the country in the majority of the population is Muslim whereby there are many Sharia expert, then they will use the specific screening model and applied only in the country, while for the country that the majority is not Muslim, then they will tend to use models of screening that has been used globally for example DJIM, FTSE, etc. This second pattern has been applied by Singapore, Thailand and Philippines. Secondly, differences in shariah screening models influenced by several factors, namely; differences in social structure of a country where the Islamic stock market is located; the difference in the financial industry that exist in the country will affect on the difference of screening models; and differences sect embraced by most scholars in a country is one of the fundamental factors in determining stock screening model of sharia in 5 ASEAN Countries.

Saham syariah merupakan salah satu sector yang mengalami pertumbuhan paling siginifikan pada beberapa tahun terakhir ini. Salah satu elemen penting dalam saham syariah yang sampai saat ini masih memiliki banyak isu adalah screening saham syariah. Tujuan dari penelitian ini adalah mengkaji model screening saham syariah yang ada di negara-negara ASEAN. Hal ini sangat penting dalam upaya menghadapi masyarakat ekonomi ASEAN 2015. Selain itu penelitian ini bertujuan untuk mengkaji beberapa factor yang mempengaruhi adanya perbedaan model screening yang ada di 5 Negara ASEAN. Dengan menggunakan metode diskriptif dan dengan pendekatan studi literature, penelitian ini menemukan beberapahal. Pertama, terdapat berbagai model screening saham syariah yang ada di Indonesia, Malaysia, 
ljtihad, Jurnal Wacana Hukum Islam dan Kemanusiaan, Volume 16, No. 2, Desember 2016: 197-216

Singapura, Thailand dan Filipina. Dalamkonteks ini, model screening di negara ASEAN memiliki dua kecenderungan yaitu; bagi negara dengan basis Muslim di mana di sana terdapat banyak ahli syariah, maka mereka akan menggunakan model screening yang spesifik dan berlakuhanya di negara tersebut, sedangkan bagi negara yang mayoritas bukan Muslim, maka mereka akan cenderung menggunakan model screening yang telah digunakan secara global misalnya DJIM, FTSE, dll. Pola kedua ini dianut oleh Singapura, Thailand dan Filipina. Kedua, perbedaan model screening syariah dipengaruhi oleh beberapa faktor, yaitu; perbedaan struktur masyarakat suatu negara di mana pasar saham syariah itu berada; adanya perbedaan industri keuangan yang ada pada negara tersebut akan mempengaruhi perbedaan model screening yangh ada; danadanya perbedaan mazhab yang dianut oleh sebagian besar ulama pada suatu negara merupakan salah satu faktor yang fundamental dalam penentuan model screening saham syariah di 5 Negara ASEAN.

Keywords: Syariah stock; Stock screening, ASEAN Economic Community; Qualitative screening, Quantitative screening.

\section{Pendahuluan}

Pasar modal syariah merupakan salah satu industri keuangan yang mengalami pertumbuhan sangat signifikan di negara-negara ASEAN pada beberapa dekade terakhir ini (Kassim, 2010; 76). Saat ini pertumbuhan dari pasar modal syariah adalah sebesar 20\%-30\% per tahun. Angka ini tentu jauh melebihi angka pertumbuhan industri keuangan konvensional yang ditaksir mengalami pertumbuhan pada kisaran 5\%-10\% (Majid and Kassim, 2010; 103-126).

Terdapat beberapa faktor yang mampu mendorong pertumbuhan industri pasar modal syariah. Pertama, adanya krisis keuangan global dengan intensitas yang semakin besar membuat kebutuhan dari masyarakat bawah terhadap sistem keuangan yang lebih adil semakin meningkat.Kedua, pertumbuhan indsutri keuangan syariah lain yaitu perbankan syariah, asuransi syariah dll menimbulkan perlunya dukungan dari sektor pasar modal. Ketiga, semakin besarnya jumlah Sumber Daya Manusia (SDM) yang memiliki pemahaman (awareness) secara lebih baik terhadap sistem keuangan syariah memberikan dorongan yang luar biasa terhadap pengembangan pasar modal syariah.

Secara teori, pasar modal syariah adalah pasar modal yang memperdagangkan instrumen keuangan yang sesuai dengan aturan-aturan dan prinsip syariah (Dusuki, 2011; 25-40). Terdapat beberapa prinsip utama dalam pasar modal syariah yaitu; adanya pelarangan riba; pelarangan gharar, pelarangan maysîr, dan perusahaan yang menerbitkan instrumen keuangan tersebut 
memiliki usaha yang tidak dilarang oleh syariah, misalnya usaha perjudian, minuman keras (Ardiansyah and Qoyum, 2012; 1028).Untuk memberikan jaminan tentang apakah suatu saham perusahaan telah sesuai syariah atau belum, saham harus diseleksi terlebih dahulu, atau yang dikenal dengan istilah shariah screening (Derigs dan Marzban, 2008; 286). Dalam proses syariah screening ini maka sebuah saham dapat dikategorikan sesuai syariah apabila telah melalui proses penyaringan dengan menggunakan beberapa kriteria atau standar yaitu; kesesuainya terhadap prinsip syariah; memenuhi seleksi quantitative yang dilihat dari sisi kinerja keuangannya; dan harus memenuhi kriteria kualitatif terkait dengan image sebuah perusahaan, kemanfaatan perusahaan tersebut terhadap ummat.

Screening yang dilakukan terhadap saham-saham syariah ini secara teori akan memiliki beberapa implikasi; pertama, saham yang telah lolos dalam proses screening maka akan dapat dikategorikan sebagai daftar efek syariah (DES)atau Shariah Compliance Securities, kedua, adanya screening yang ketat pada sisi kinerja keuangan, maka saham syariah merupakan saham yang memiliki kinerja terbaik dibandingkan yang lain; ketiga, saham syariah adalah saham yang kemungkinan memiliki probabibilitas volatility cukup rendah dan lebih tahan terhadap goncangan yang terjadi dalam suatu perekenomian, misalnya krisis keuangan.

Dalam proses screeningsaham syariah, setiap negara memiliki standar yang berbeda-beda (Derigs dan Marzban, 2008; 289). Dengan standard yang berbeda ini, tentu mekanisme dan prosedur screeningnya juga berbeda. Di Indonesia sendiri misalnya, untuk masuk kategori sebagai saham syariah maka sebuah saham harus memenuhi beberapa tahapan seleksi yaitu seleksi kualitatif berkaitan dengan pemenuhan terhadap prinsip syariah dan seleksi quantitative yaitu sebuah perusahaan yang menerbitkan saham harus memiliki rasio keuangan, Interest Income \& Income from Non-Shariah compliantbusiness activities/Total Revenue $<10 \%$ dan Interestbearing debt/Total Equity < 82\% (Fatwa Dewan Syari'ah Nasional No: 40/DSN-MUI/X/ 2003). Sedangkan di negara lain misalnya Malaysia shariah screening harus melalui dua tahapan yaitu; tahap kuantitatif, dan tahap kualitatif (Derigs dan Marzban, 2008; 251).

Perbedaan model standar dalam screening saham syariah ini tentu menimbulkan beberapa persoalan. Isu shariah menjadi mengemuka mengingat perbedaan ini mencerminkan kerancuan dalam sistem keuangan syariah. Karena, jika sumber rujukannya sama, tentu akan lebih baik jika standard syariah juga sama. Selain itu, model screening yang berbeda juga 
ljtihad, Jurnal Wacana Hukum Islam dan Kemanusiaan, Volume 16, No. 2, Desember 2016: 197-216

memberikan indikasi bahwa kualitas dari suatu saham yang sesuai syariah juga berbeda, tergantung pada seberapa ketat/baik kriteria dan seleksi yang dilaksanakan. Kualitas ini dapat dilihat dari kinerja dari saham tersebut yang diukur dengan return yang di hasilkan, volatilitas, dan ketahanannya dalam menghadapi goncangan (shock) dalam suatu perekonomian. Ketiga, dalam konteks integrasi masyarakat ASEAN dan mungkin integrasi pasar keuangan Islam, perbedaan ini menimbulkan kerancuan dan kebingungan bagi masyarakat Islam.Berdasarkanrumusanmasalah di atas, makatujuanpenelitianiniadalahuntuk mengetahui dan memahami tentang bagaimanakah model screening pasar modal syariah yang dilakukan beberapa negara ASEAN serta mencari solusi harmonisasinya.

\section{Penelitian terdahulu}

Penelitian yang dilakukan oleh Herwany dan Febrian (2009;18) menemukankan adanya volatilitas yang tinggi dari pasar saham syariah di Indonesia. Tingginya volatilitas portofolio saham syariah mencerminkan perlunya Dewan Syariah Indonesia untuk mempertimbangkan kembali nilai pasar dalam menentukan kriteria syariah(Herwany dan Febrian , 2010; 22)

Derigs dan Marzban (2009; 11), menemukan bahwa portofolio saham-saham syariah memiliki kinerja yang sama dengan portfolio konvensional.Sementara itu Guyot $(2012 ; 22)$, menggunakan Indek saham Islamic Dow Jones, menemukan bahwa saham-saham syariah memiliki sensitifitas yang lebih tinggi terhadap isu-isu geopolitik, seperti isu krisis subprime mortgage di USA.Mamun demikian, hasil penelitian berbeda ditemukan oleh Derbel, Bouraoui dan Dammak (2011; 9), dimana dengan menggunakan VAR Model, penelitian mereka menemukan bahwa model pasar saham syariah dapat mengurangi dampak krisis keuangan yang terjadi.

Berkaitan dengan shariah screening, Sani dan Othman (2013) melakukan penelitian tentang revisi metode shariah screening berdasarkan pada kondisi perusahaan-perusahan yang memenuhi kriteria shariah. Penelitian tersebut memberikan kesimpulan bahwa 77\% dari saham yang telah dinyatakan sebagai saham syariah dengan model screening dewan syariah Malaysia tetap layak memenuhi aspek syariah. Artinya, dari jumah tersebut masih terdapat 23\% yang tidak sesuai syariah namun masuk dalam daftar efek syariah. Sedangkan saham syariah yang diseleksi dengan menggunakan metodologi MSCI, hanya ada 39\% dari 
perusahaan akan berhak status sesuai syariah(Sani dan Othman, 2013; 51-63)

Dari beberapa literatur di atas, peneliti melihat bahwa memang banyak penelitian yang membahas tentang volatilitas saham syariah serta kaitannya dengan variabel makroekonomi, namun masih belum ada penelitian yang melihat bagaimana pengaruh perbedaan penggunaan model screening saham syariah terhadap ketahanan dan volatilitas pasar saham. Selain itu, penelitian tentang model screening juga masih terfokus pada masing-masing negara. Oleh karena itu, penelitian ini akan meneliti bagaimanakah perbedaan model screening saham terjadi di berbagai negara di Asia Tenggara, dan jika berbeda, bagaimana dampaknya terhadap ketahanan dan volatilitas saham syariah. Pada akhirnya penelitian ini diharapkan dapat menjadi bahan masukan dalam mewujudkan harmonisasi atau standarisasi model screening saham secara internasional.

\section{Tujuan syariah (maqāṣid al-sharī'ah)}

Perkembangan pasar modal syariah tidak terlepas dari isu pengembangan pasar modal pada umumnya yang memainkan peranpenting untuk menarik tabungan dan menyalurkannya untuk tujuan produktif.Selain itu pasar modal syariah juga merupakan sistem integral dengan sistem ekonomi Islam yang tujuan utamanya adalah untuk mewujudkan tujuan syariah (maquassid al-shari'ah).

Menurut Imam Ghazali, “Tujuan syariah adalah untuk mempromosikan kesejahteraan kepada seluruh umat manusia, yang terletak dalam terlindunginya iman mereka (din), dirinya manusia (nafs), akal mereka ('aq), keturunan mereka (nash) dan kekayaan mereka (mā) (alGhazali: 1997; 204). Sedangkan menurut Imam Syathibi (t.t.) kemudian membagi maslahat ini kepada tiga bagian penting yaitu daruriyyat (primer), bajiyyat (skunder) dan tabsinat (tersier).

Adabeberapa karakteristik khusus Pasar Modal Syariah yaitu bahwa produk dan mekanisme transaksi tidak bertentangan dengan prinsip-prinsip syariah. Namun demikian, tidak semua saham yang diterbitkan oleh Emiten dan Perusahaan Publik dapat disebut sebagai saham syariah. Suatu saham dapat dikategorikan sebagai saham shariah apabila telah melewati screening shariah. Tujuan dari screening saham syariah adalah untuk memastikan bahwa suatu saham telah memenuhi semua aspek syariah. Pada umumnya terdapat dua tahapan dalam proses screening yaitu; Melakukan evaluasi terhadap aktivitas perusahaan, produkdan 
ljtihad, Jurnal Wacana Hukum Islam dan Kemanusiaan, Volume 16, No. 2, Desember 2016: 197-216

industri;Menghitung beberapa rasio keuangan dan membandingkannya dengan benchmarknya (Omar et. al., 2013; 67)

Di Indonesia suatu saham dapat dikategorikan sebagai saham syariah jika saham tersebut diterbitkan oleh perusahaan yang kegiatan usahanya tidak bertentangan dengan prinsip-prinsip syariah, namun memenuhi kriteria tidak melakukan kegiatan usaha: perjudian; perdagangan yang tidak disertai dengan penyerahan barang/jasa; perdagangan dengan penawaran/ permintaan palsu; bank berbasis bunga; perusahaan pembiayaan berbasis bunga; gharar dan maysir, memproduksi, mendistribusikan, memperdagangkan dan/atau menyediakan barang atau jasa yang haram; melakukan transaksi yang mengandung unsur suap (risywah) (Fatwa Dewan Syari'ah Nasional No: 40/DSN-MUI/X/2003).

Dalam pasar modal syariah juga terdapat beberapa transaksi yang dilarang oleh syariah yaitu; Tadlis, tindakan menyembunyikan informasi; Taghrir, upaya mempengaruhi orang dengan penawaran palsu; Ikbtikar, menimbun, dengan tujuan untuk menjual kembali pada saat harga lebih mahal; Ghishsh, penjual menyembunyikan kecacatannya; Ghabn Fahish, merupakan ketidakseimbangan antara dua barang yang dipertukarkan dalam suatu akad.

\section{Pasar modal dan spekulasi}

Pasar modal sebagai bagian daripada sistem ekonomi konvensional, pasar modal tidak terlepas dari salah satu persoalan yang sangat serius dalam operasionalnya. Salah satunya adalah tindakan spekulasi. Spekulasi merupakan aktivitas yang melakukan jual-beli saham dengan tujuan untuk mendapatkan keuntungan dalam jangka pendek. Keuntungan ini dapat diperoleh dari adanya perbedaan harga saham ketika membeli dengan menjual. Aktivitas ini menjadi bagian yang utuh dan tidak dapat dipisahkan dari keberadaan pasar saham saat ini.

Dalam pasar modal ini, dibedakan antara spekulan dengan pelaku bisnis (investor) dari derjat ketidak pastian yang dihadapinya. Untuk itu perlu dilihat dahulu karakter dari masingmasing investasi dan spekulasi, Pertama, Investor di pasar modal adalah mereka yang memanfaatkan pasar modal sebagai sarana untuk berinvestasi di perusahaan-perusahaan gopublik yang diyakini baik dan menguntungkan, bukan untuk tujuan mencari capital gain melalui short selling. Mereka mendasari keputusan investasinya pada informasi yang terpercaya tentang faktor-faktor fundamental ekonomi dan perusahaan itu sendiri melalui kajian yang 
seksama. Sementara spekulan bertujuan untuk mendapatkan gain yang biasanya dilakukan dengan upaya "goreng menggoreng" saham.

Kedua, spekulasi sesungguhnya bukan merupakan investasi, meskipun di antara keduanya ada kemiripan. Perbedaan yang sangat mendasar di antara keduanya terletak pada motiv yang mendasarinya. Para spekulan membeli sekuritas untuk mendapatkan keuntungan (capital gain) dengan menjualnya kembali dalam jangka pendek. Sedangkan para investor membeli sekuritas dengan tujuan untuk berpartisipasi secara langsung dalam bisnis yang lazimnya bersifat long term.

Dalam Islam sendiri, ada banyak perbedaan tentang apakah spekulasi diperbolehkan atau tidak. Dalam nash al-Quran yang secara jelas dilarang adalah kegiatan maysir dan gharar. Jual beli yang dilakukan dengan mengandung unsur gharar jelas dilarang, karena akan mendatangkan madharat. Adanya gharar inilah yang menimbulkan potensi maysir. Maysir lebih mirip dengan kegiatan judi atau zero sum game sebagaimana dalam al-Qur'an(2: 219).

Rasulullah (SAW) juga melarang kita dari perjudian seperti digambarkan dalam hadis berikut;

"Dari Abu Hurairah (RA), bahwa ia berkata, "Rasul Allahmelarang 'penjualan kerikil' (penjualan obyek yang dipilih atau ditentukan oleh pelemparan kerikil), dan penjualan algharar(Sahih Muslim)"

Ada perbedaan pandangan dari para ulama tentang, apakah kegiatan spekulasi termasuk sebagai bagian dari maysir atau tidak. Ibnu Taymiyyah berpendapat bahwa hadith di atas merupakan hadis tentang ghararsebagai konsekuensi dari ketidaktahuan. Maysir atau perjudian dilarang dalam Islam karena menyebabkan permusuhan dan kebencian dan juga melibatkan memakan properti bi-al-batil, yang merupakan jenis penindasan. Diberi larangan perjudian jelas dalam Al-Quran dan Hadis Nabi (SAW), itu adalah sangat penting untuk menentukan apakah spekulasi di pasar saham mirip dengan judi.

Kamali (1996; 199) mendefinisikan spekulasi sebagai terdiri dari "peramalan cerdas dan rasional tentang tren harga suatu aset di masa depan berdasarkan pada bukti dan pengetahuan tentang kondisi masa lalu dan sekarang". Berdasarkan ayat-ayat Al-Quran dan Hadis Nabi (SAW), Ibnu Taimiyyahmengatakan bahwa jika penjualan mengandung gharar dan memakan milik orang lain, itu adalah sama seperti perjudian, yang jelas-jelas dilarang. Oleh karena itu, untuk transaksi yang 
ljtihad, Jurnal Wacana Hukum Islam dan Kemanusiaan, Volume 16, No. 2, Desember 2016: 197-216

akan disamakan dengan judi, itu harus melibatkan melahap dan perampasan tidak sah milik orang lain.Risiko spekulatif mengambil dalam perdagangan, yang melibatkan investasi dari aset, keterampilan dan tenaga kerja tidak sama dengan perjudian. Hal ini karena pembeli terlibat dalam transaksi yang bertujuan untuk membuat keuntungan melalui perdagangan dan bukan melalui perampasan jujur dari milik orang lain (Omar et.al: 2013; 147).

Sementara itu, El-Ashkar (1995; 81-83) mendefinisikan spekulasi sebagai sebuah praktek yang menggunakan informasi yang tersedia untuk mengantisipasi pergerakan harga masa depan dari sebuah sekuritas sehingga tindakan membeli atau menjual sekuritas dapat diambil dengan maksud untuk membeli atau menjual sekuritas untuk mendapatkan capital gain dan atau memaksimalkan nilai kapitalisasi kepemilikan saham.Ini adalah proses yang bergantung pada analisis banyak data ekonomi dan keuangan, laporan keuangan perusahaan, keputusan politik, informasi mengenai keterampilan manajemen dan bakat dan profil pribadi para pengambil keputusan. Artinya, spekulasi adalah kegiatan yang membutuhkan banyak pengetahuan dan keterampilan. Oleh karena itu, berdasarkan pada beberapa pendapat di atas maka spekulasi di pasar saham tidak bisa disamakan dengan perjudian.Hal ini karena, spekulasi di pasar saham masih mendasarkan pada pengetahuan, ilmu serta data ekonomi yang ada untuk membuat keputusan.

Pembahasan di atas telah membuktikan bahwa meskipun spekulasi di pasar saham mungkin terlihat seperti perjudian, namun tidak sama. Sisi positif adalah bahwa hal itu dapat membantu menstabilkan harga dan mengaktifkan pasar di mana ada perdagangan tipis. Hal ini juga dapat memberikan sinyal kepada investor kurang informasi yang di atasnya untuk bertindak. Efek negatif dari spekulasi adalah bahwa jumlah yang berlebihan dapat menyebabkan pergerakan harga stabil di pasar. Dengan demikian dapat disimpulkan bahwa spekulasi yang berlebihan seharusnya tidak diperbolehkan, tetapi pada tingkat wajar diijinkan. Batas kuantitatif pada volume perdagangan harian dan pedoman legislatif dapat membantu mengandung spekulasi dalam batas-batas yang sehat.

Sementara itu ada juga berpandangan bahwa Islam secara tegas melarang tindakan spekulasi sebab secara diametral bertentangan dengan nilai-nilai illahiyah dan insaniyyah. Tindakan ini juga memicu timbulnya aksi-aksi kecurangan yang terjadi dibursa saham seperti terjadinya skim Ponæi, Frauds in trading ataupun short selling. 


\section{Metode penelitian}

Populasi yang digunakan dalam penelitian ini adalah otoritas pasar modal syariah serta keseluruhan perusahaan non-keuanganyang terdaftar di Bursa Efek Indonesia dan Kuala Lumpur Stock Exchange (KLSE), Bursa Efek Singapora, Bursa Efek Thailand dan Bursa Efek Filipina periode Januari 2005-April 2014. Penelitian inimenggunakan dua jenis data yaitu data primer dan data sekunder. Untuk mengetahui model screening di 5 negara ASEAN dan faktor-faktor yang mempengaruhi perbedaan tersebut menggunakan data primer.

Penelitian ini menggunakan teknik pengumpulan data melalui metode wawancara, yaitu suatu cara untuk mendapatkan informasi dengan cara bertanya secara langsung kepada responden. Wawan cara dilakukan dengan responden yang berasal dari para ahli keuangan syariah, regulator pasar modal syariah serta dewan syariah nasional khususnya di Indonesia dan Malaysia, misalnya Dewan Syariah Nasional, Islamic Shariah Academy, Islamic Financial Service Board, dan Otoritas Jasa Keuangan. Hasil dari wawancara ini, diharapkan dapat memberikan gambaran tentang perbedaan model screening saham syariah dan kemungkinan untuk membuat standar internasional.

Penelitian ini menggunakan beberapa model teknik analisa data, sesuai dengan pertanyaan penelitian yang akan dijawab. Untuk pertanyaan pertama dan kedua, maka teknik analisa yang digunakan adalah teknik analisa kualitatif dengan melihat, membandingkan dan menganalisa berbagai model screening saham syariah.

\section{Metode-metode stock screening di lima negara ASEAN}

Stockscreening merupakan hal yang paling penting dalam industri pasar modal syariah, karena dalam aktivitas ini saham akan ditentukan apakah sesuai dengan syariah atau tidak. Dalam proses screening saham, penelitian ini menemukan bahwa 5 Negara ASEAN yang menjadi objek penelitian ini menggunakan model yang berbeda-beda. Secara umum, proses screening saham dilakukan melalui dua tahapan yaitu tahapan kualitatif dan tahapan kuantitatif. Tahap kualitatif, proses screening meneliti tentang aktivitas utama dari perusahaan yang menerbitkan saham. Di Jakarta Islamic Index, saham akan dievaluasi berdasarkan ada atau tidaknya beberapa aktivitas yang dilarang yaitu;perjudian dan mainan, perdagangan yang dilarang, lembaga keuangan konvensional, transaksi yang berbau korupsi, memproduksi barang atau 
ljtihad, Jurnal Wacana Hukum Islam dan Kemanusiaan, Volume 16, No. 2, Desember 2016: 197-216

jasa yang merusak moral. Setelah suatu saham dinyatakan lolos pada tahap pertama, maka pada tahapan selanjutnya, saham akan dievaluasi dengan menggunakan beberapa rasio keuangan yaitu; rasio pendapatan bunga/pendapatan dari aktivitas non-halal terhadap total pendapatan kurang dari $10 \%$, serta rasio hutang berbasis bunga terhadap total equity kurang dari $82 \%$.

Tabel 1

Tahap 1: Activity, Industry, and Products Screening

\begin{tabular}{|c|c|c|c|c|}
\hline $\begin{array}{l}\text { MSCI Islamic } \\
\text { Index } \\
\text { (Philippine) }\end{array}$ & $\begin{array}{l}\text { FTSE Islamic } \\
\text { Index } \\
\text { (Singapore) }\end{array}$ & $\begin{array}{c}\text { Jakarta Shariah } \\
\text { Index } \\
\text { (Indonesia) }\end{array}$ & $\begin{array}{l}\mathrm{SAC}(\mathrm{SC}) \\
\text { (Malaysia) }\end{array}$ & $\begin{array}{c}\text { DJIM } \\
\text { (Thailand) }\end{array}$ \\
\hline Negative Screen & $\begin{array}{c}\text { Non Permissible } \\
\text { Activities }\end{array}$ & Negative Screen & Fxcludes & $\begin{array}{c}\text { Non Permissible } \\
\text { Activities }\end{array}$ \\
\hline Alcohol & Pork Production & $\begin{array}{c}\text { Gambling and Games } \\
\text { Considered as } \\
\text { Gambling }\end{array}$ & $\begin{array}{c}\text { Financial Services Based on } \\
\text { Riba }\end{array}$ & Pork Production \\
\hline Tobacco & $\begin{array}{l}\text { Non-Halal Food } \\
\text { Products }\end{array}$ & $\begin{array}{c}\text { Trading that is } \\
\text { Prohbited } A \text { coording to } \\
\text { Shariah }\end{array}$ & Gambling/Gaming & Tobacco \\
\hline $\begin{array}{l}\text { Pork-rclated } \\
\text { Products }\end{array}$ & $\begin{array}{c}\text { Alcohol } \\
\text { Beverages }\end{array}$ & $\begin{array}{l}\text { Conventional Financial } \\
\text { Institutions }\end{array}$ & $\begin{array}{l}\text { Manufacture and or Sale of } \\
\text { Non Halal Products }\end{array}$ & Alcohol \\
\hline $\begin{array}{l}\text { Conventional } \\
\text { Financial Services }\end{array}$ & Gambling & $\begin{array}{l}\text { Transaction that } \\
\text { Contain Elements of } \\
\text { Bribery (Risywah) }\end{array}$ & Tobacco & Gaming \\
\hline Defense/weapon & $\begin{array}{l}\text { Interest Based } \\
\text { Financial } \\
\text { Institution }\end{array}$ & $\begin{array}{l}\text { Products or Services } \\
\text { that can Deprave one's } \\
\text { Morals and are } \\
\text { Harmful }\end{array}$ & Conventional Insurance & $\begin{array}{l}\text { Convenntional } \\
\text { Financial } \\
\text { Services }\end{array}$ \\
\hline Gambling & $\begin{array}{l}\text { Entertainment } \\
\text { (Casinos, elc.) }\end{array}$ & & Entertainment & Entertainment \\
\hline Music & Arms, Defense & - & $\begin{array}{l}\text { Stock-Broking or Share } \\
\text { Trading in Shariah Non- } \\
\text { Compliant Securities }\end{array}$ & Defense, Weapon \\
\hline IIotels & Tobaceo & - & - & Non Halal Food \\
\hline Cinema & $\begin{array}{c}\text { Activities } \\
\text { Contrary to Islam }\end{array}$ & Jakarta Shariah Index & $\mathrm{SAC}(\mathrm{SC})$ & $\begin{array}{c}\text { Activities } \\
\text { Contrary to Islam }\end{array}$ \\
\hline $\begin{array}{c}\text { Adult } \\
\text { Entertainment }\end{array}$ & - & Negative Screen & Excludes & - \\
\hline
\end{tabular}


Sementara itu, model screening saham-saham syariah di Singapura menggunakan standar yang selama ini banyak digunakan oleh FTSE. Dalam model ini, saham syariah menggunakan dua tahapan, yaitu tahapan kualitatif dan kuantitatif. Pada tahap kuantitatif mekanisme yang dijadikan standard oleh FTSE hampir sama dengan yang dipakai oleh Jakarta Islamic Index (JII), namun dengan beberapa elemen perbedaan yaitu; perusahaan yang memproduksi senjata dan perusahaan yang bergerak dalam bidang hiburan (entertainment) akan dikeluarkan sebagai saham yang sesuai syariah.

Untuk tahap kuantitif, FTSE yang digunakan di pasar modal syariah di Singapura akan menggunakan beberapa variabel keuangan yaitu; rasio kas ditambah piutang terhadap total asset kurang dari 50\%; rasio kas ditambah sekuritas berbasis bunga terhadap total aset adalah kurang dari 33\%; non halal income kurang dari 5\% serta rasio total hutang terhadap total aset kurang dari $33 \%$.

Tabel 2

Financial Screening DJIM dan MSCI

\begin{tabular}{|c|c|c|}
\hline & DJIM & MSCI Islamic Index \\
\hline & $A c c \operatorname{Rec}$ & Totl Cash + Account Receivables \\
\hline & 24 Mth Average Market Cap $<33 \%$ & $\begin{aligned} & \text { Total Assets } \\
&<33.33 \%\end{aligned}$ \\
\hline \multicolumn{3}{|l|}{ Liquidity } \\
\hline & Cash + Int. Bearing Sec. & Cash + Interest - Bearing Sec. \\
\hline & $\begin{array}{c}\overline{24 \text { Mth Average Market Cap. }} \\
<33 \%\end{array}$ & $\begin{array}{c}\text { Total Assets } \\
<33.33 \%\end{array}$ \\
\hline Debt & $\begin{array}{c}\text { Total Debt Divided by Trading } 24 \\
\text { Month Average Market Capitalization } \\
<33 \%\end{array}$ & Tolal Debl/Tolal Asscts $<33.33 \%$ \\
\hline
\end{tabular}

Filipina menggunakan model screening MSCI. Pada model ini, pada umumnya menggunakan dua tahapan sebagaimana terjadi pada model lain. Dalam tahapan kualitatif, MSCI akan menyeleksi apakah suatu saham dapat masuk ke dalam saham syariah atau tidak dengan melihat aktivitas utamanya, produk mereka serta sektor industrinya. Beberapa elemen 
ljtihad, Jurnal Wacana Hukum Islam dan Kemanusiaan, Volume 16, No. 2, Desember 2016: 197-216

yang berbeda pada tahapan MSCI ini adalah perusahaan mainan anak-anak, perusahaan musik, dan bioskop akan dikeluarkan sebagai perusahaan yang sesuai syariah. Selain itu, perusahaan yangbergerak dalam bidang perhotelan juga tidak masuk kategori perusahaan yang sesuai syariah. Sedangkan untuk model kuantitatif nya,saham syariah menggunakan beberapavariabel utama yaitu; rasio likuiditas kurang dari 33.33\% dan rasio total hutang terhadap total aset kurang dari $33.33 \%$.

Tabel 3

\begin{tabular}{|c|c|c|c|}
\hline & FTSE Islamic Index & Jakarta Islamic Index & SAC \\
\hline \multirow[t]{2}{*}{ Liquidity } & $\frac{\text { Acc. } R e c .+ \text { Cash }}{\text { Total Assets }}<50 \%$ & - & $\begin{array}{l}\text { Turnover (TO) } \\
\text { and Profit } \\
\text { Bcforc Tax } \\
\text { (PRT) ofnon } \\
\text { approve } \\
\text { activities Must } \\
\text { Below Certain } \\
\text { Level }\end{array}$ \\
\hline & $\begin{array}{r}\text { Cash }+ \text { Int Bearing Sec. } \\
\text { Total Assets } \\
<33 \%\end{array}$ & - & $\begin{array}{l}\text { Interest } \\
\text { Income }\end{array}$ \\
\hline $\begin{array}{l}\text { Prohibite } \\
\text { d Income }\end{array}$ & $\begin{array}{l}\quad \frac{\text { Interest Income }}{\text { Group Turnover }}<5 \% \\
\text { Non Permissible Income } \\
\text { other than Intereset Income } \\
\text { Revenue }\end{array}$ & $\begin{array}{l}\text { Interest Income } \\
\text { Income from Non - } \\
\text { Shariah Complian } \\
\frac{\text { Business Activiles }}{\text { Total Revenue }}<10 \%\end{array}$ & $\begin{array}{l}\text { Dividend } \\
\text { received from } \\
\text { investment in } \\
\text { non-approved } \\
\text { securities. }\end{array}$ \\
\hline Debt & $\frac{\text { Total Debt }}{\text { Total Asset }}<33 \%$ & $\begin{array}{c}\frac{\text { Interest }- \text { bearing debt }}{\text { Total Equity }} \\
<82 \%\end{array}$ & \\
\hline
\end{tabular}


Sementara itu, untuk pasar saham syariah di Thailand menggunakan model yang dikeluarkan oleh Dowjones Islamic Market. Dalam model tersebut, saham akan diklasifikasikan dengan menggunakan bebapa indikator kualitatif sebagaimana yang digunakan pada model lain. Beberapa rasio keuangan akan digunakan untuk melakukan penyaringan saham syariah yaitu rasio likuiditas (rasio piutang/24bln kapitalisasi aset dan rasio kas dan sekuritas berbasis hutang terhadap 24bulan kapitilasisasi pasar aset) kurang dai 33\%, serta rasio hutang terhadap kapitalisasi pasar kurang dari 33\%.

Dari beberapa model screening saham syariah, model yang digunakan di Malaysia adalah model yang paling unik dibandingkan yang lain. Model yang dikeluarkan oleh Syariah Advisory Council pasar modal syariah di Malaysia, selain menggunakan model kriteria kualitatif sebagaiamana yang ada di beberapa model lain, Malaysia juga menetapkan beberapa kriteria lain yaitu; image; kebutuhan umum (macla\%ah); adat kebiasaan ("urf); umûm al-balwa (common plight); hak non-muslim.

Sementara itu, untuk kriteria kuantitatif, pasar saham syariah menggunakan beberapa variabel keuangan yaitu rasio total aktivitas non-halal terhadap total turnover dan rasio total aktivitas non-halal terhadap laba sebelum pajak. Adapun untuk ukuran atau batasan rasio tersebut, pasar saham Malaysia menggunakan beberapa standar yaitu; The five-percent $(5 \%)$ benchmark, The 10-percent (10\%) benchmark, The 20-percent (20\%) benchmark.

Proses screening didesain untuk melakukan identifikasi terhadap elemen-elemen yang bertentangan dengan aturan syariah, yang bersumber dari Al-Qur'an dan Hadits. Hukum syariah melarang beberapa elemen seperti riba, maysîr dan gharar. Semua elemen tersebut sangatlah biasa dilakukan di dalam sistem konvensional. Bagi seorang muslim, perbuatan tersebut tentu bertentangan dengan aturan dan merupakan perbuatan dosa.

Bersamaan dengan berdirinya bank syariah, maka pengenalan produk-produk syariah menjadi hal yang cukup penting. Beberapa orang mengatakan bahwa keberadaan produkproduk syariah tersebut hanyalah sebatas replikasi dari sistem konvensional. Semua produkproduk keuangan syariah sebelum mendapatkan pengesahan sebagai produk halal maka harus malalui tahapan screening terlebih dahulu yang dilakukan oleh Dewan Syariah di masingmasing negara sesuai dengan kewenangannya. 
ljtihad, Jurnal Wacana Hukum Islam dan Kemanusiaan, Volume 16, No. 2, Desember 2016: 197-216

Dewan syariah inilah yang akan memastikan bahwa setiap produk keuangan yang dikeluarkan berada dalam kerangka syariah. Beberapa produk perbankan syariah yang ada misalnya produk murabahah, musyarakah, ijarah telah cukup populer selama ini. Namun demikian, dalam dunia keuangan seperti sekarang ini, masih dibutuhkan jenis-jenis produk yang lain sesuai dengan kebutuhan masyarakat. Dalam pasar saham, keberadaan saham syaiah tentu sangatlah penting mengingat masyarakat yang sangat membutuhkan. Shariah screening merupakan salah satu kegiatan yang dilakukan untuk menghilangkan produk-produk yang tidak sesuai dengan syariah dan tidak sesuai dengan kaidah investasi dalam Islam (Dusuki, $2012 ; 130)$.

Meningkatnya kesadaran dari investor muslim dalam aktivitas perdagangan saham adalah menjadi salah satu alasan penting perlunya pengembangan metode screening saham syariah. Aktivitas yang sangat lekat dengan riba merupakan salah faktor yang menentukan larinya investor muslim dari pasar saham. Oleh karena itu, pada tahun 1987, para ahli berkumpul dan memberikan solusi tentang bagaimanakah agar para investor muslim dapat memperoleh suatu manfaat dari pasar saham. Muhammad Taqi Usman sebagai ketua tim bersama dengan Prof. Saleh Tug dan Sheikh Muhammad Al-Tayeb Al-Najjarmempresentasikan kriteria shariah screening termasuk dalam kaitan bagaimanakah seorang investor Muslim melakukan jual beli saham syariah (Mian, 2008; 25-39).

Mencari petunjuk dari para ulama merupakan upaya yang terus dilakukan dalam mengembangkan produk keuangan Islam. Praktek ini telah berlangsung lama mulai dengan meminta pandangan dari para imam masjid. Konsultasi informal ini yang kemudian berkembang dengan proses yang lebih luas yakni dengan membuat metode screening yang diterima secara luas di seluruh dunia. Dalam kontek aktivitas ekonomi dan keuangan, petunjuk dan arahan ini tentu sangatlah penting untuk menjamin bahwa setiap transaksi ekonomi telah sesuai dengan syariah (Mian, 2008; 25-39).

Penasehat syariah adalah seorang ulama yang memiliki keahlian dalam bidang fiqh muamalah dan keuangan Islam, yang memiliki kewajian untuk mengarhkan, mereview dan mengawasi segala kativitas yang berhubungan dengan keuangan Islam, untuk menjamin bahwa semua produk keuangan Islam sesuai dengan aturan dan prinsip syariah.Bagian dari seorang ahli syariah dalam keuangan Islam sangatlah penting. Misalnya, terdapat kasus di 
mana hal itu tidak terdapat pada masa Rasulullah SAW dan membutuhkan penjelasan, maka pendapat dari para ahli syariah ini tentu sangat penting untuk mencari solusi berdasarkan pada sumber-sumber lain yakni ijma dan qiyas yang berorientasi maslahah bagi masyarakat.

Secara esensi, pandangan dari para ahli syariah dalam proses screening saham syariah merupakan sebuah bentuk layanan kepada ummat untuk mewujudkan maslahah, tidak seperti ahli hukum konvensional yang menympaikan pendapat hukum dengan menerima sejumlah fee. Atas dasar inilah maka, ahli syariah harus lebih hati-hati dalam memberikan pandangan dalam proses screening. Sebagaimana dijelaskan oleh De Lorenzo, bahwa pengawasan syariah mungkin akan dianggap sebagai sebuah audit syariah. Sehingga secara spesifik, pengawasan syariah dalam proses screening merupakan bentuk upaya untuk menjamin bahwa produk dan jasa yang ditawarkan dalam produk keuangan Islam adalah diterima secara syariah, oleh karena itu, masyarakat muslim boleh untuk menggunakannya.

Semuapendekatan dalam proses screening saham seharusnya menggunakan kriteria yang sama karena semuanya menggunakan sumber hukum yang sama. Namun demikian, pada level penerimaannya terdapat perbedaan. Hal ini karena berdasarkan pada lingkungan, lokasi dan mazhab yang dianut. Beberapa negara menggunakan model kriteria yang spesifik berlaku di tempat tersebut misalnya Malaysia dan Indonesia, sementara beberapa negara lain menggunakan model screening yang lebih diterima secara global misalnya Dowjones, FTSE dll (Derigs dan Marzban, 2008; 291). Selain itu, saat ini juga berkembang model screening yang berjalan secara otomatis, walaupun hal ini masih diperdebatkan tingkat akurasinya, karena ternyata masih ada perusahaan yang seharusnya tidak masuk sebagai daftar efek syariah tetapi ternyata lolos shariah screening (Marzban and Donia, 2010; 12).

Derigs dan Marzban (2008; 295) menggarisbawahi bahwa perbedaan standar dalam melakukan screening saham syariah memungkin terjadinya perbedaan apakah sebuah perusahaan dikatakan sebagai halal atau haram. Mereka juga berpendapat bahwa pendekatan matematis dalam proses screening mungkin kurang memiliki akurasi yang baik, jika tidak didukung dengan pengkajian secara mendalam. Rahman et.al (2010; 235) melakukan kajian tentang kriteria screening saham syariah di Kuala Lumpur Stock Exchange dan Dow Jones Islamic Market Index, di mana mereka menemukan inkonsistensi dalam proses screening dari keduanya. 
ljtihad, Jurnal Wacana Hukum Islam dan Kemanusiaan, Volume 16, No. 2, Desember 2016: 197-216

Namun demikian, hal ini memungkinkan untuk ditoleransi dengan fakta bahwa mungkin suatu negara memiliki karakteristik yang khusus dan berbeda dengan negara lain. Misalnya, Malaysia sebagai negara muslim tentau tidak dapat dibandingkan dengan negara-negara lain yang non-Muslim. Namun demikian perbedaan ini sangat berpotensi menimbulkan persaan tidak percaya dan tidak aman dari para investor terhadap produk-produk keuangan yang pada akhirnya hal ini akan menghambat proses pengembangan produk keuangan Islam pada masa yang akan datang. Oleh karena itu, sebagaimana diusulkan oleh beberapa ahli keuangan, maak perlu adanya upaya pengembangan kearah penyatuan atau standarisasi model screening saham syariah (Islamic Finance News, 2011; 15).

Melalui analisa ini, peneliti ingin menunjukkan dampak dari perbedaan pedoman syariah dalam proses screening saham dan mencoba untuk menjelaskan faktor kenapa hal itu berbeda. Berdasarkan pada analisa, penelitian ini secara jelas menunjukkan bahwa perbedaan adanya standar screening saham syariah menghasilkan perbedaan klasifikasi apakah perusahaan masuk dalam kategori perusahaan yang halal atau haram. Hal ini tentu menimbulkan inkonsistensi terhadap hasil klasifikasi, sehingga dampaknya adalah menimbulkan tingkat kepercayaan dan rasa aman dari para investor menjadi berkurang. Tentu dampak jangka panjangnya adalah terhambatnya proses pengembangan keuangan syariah pada masa yang akan datang.

Keahlian dari para ulama merupakan hal yang paling penting dalam membuat produk keuangan islam dan menjamin bahwa produk keuangan yang berkembang di konvensional dapat diakses oleh investor muslim. Penelitian ini menemukan bahwa para pengawas syariah tidak melakukan analisa secara detail pada tingkat operational utamanya berkaitan dengan rasio keuangan, sehingga hal ini menimbulkan beberapa kerancuan pada berbagai aspek karena bisa saja menurut pengawas syariah yang satu halal sementara menurut yang lain haram. Atas dasar inilah maka penyatuan dan standarisasi model screening saham syariah merupakan hal yang sangat urgen.

\section{Penutup}

Penelitian ini mengkaji berbagai aspek dalam proses screening saham untuk menentukan apakah saham tersebut termasuk dalam kategori saham yang halal atau haram. Proses screening ini tentu sangat penting untuk menarik minat para investor serta memberikan peluang kepada 
mereka yaitu investor muslim untuk merasakan manfaat dari pasar saham. Penelitian ini menekankan pada beberapa hal yaitu, bagaimanakah model screening saham syariah yang digunakan di negara ASEAN yang dalam penelitian ini sampel yang digunakan adalah Indonesia, Malaysia, Singapura, Thailand dan Filipina. Selain itu, penelitian ini juga mengkaji berbagai faktor yang mempengaruhi perbedaan dari model screening saham syariah, serta bagaimana dampak dari perbedaan ini terhadap tingkat ketahanan saham syariah dan volatilitas pasar saham syariah di 5 Negara ASEAN.

Berdasarkan pada analisa data yang kami lakukan, penelitian ini menyimpulkan beberapa hal yaitu; pertama, dari 5 sampel yang digunakan dalam penelitian ini menunjukkan bahwa 5 negara ASEAN yaitu Indonesia, Malaysia, Singapura, Thailand dan Filipina menggunakan model screening yang berbeda-beda. Indonesia menggunakan model screening yang secara spesifik digunaka di negara tersebut yaitu model kualitatif yang mengkaji kegiatan, aktivitas dan produk yang dihasilkan oleh perusahaan yang menerbitkan saham tersebut dan model kualitatif yang menggunakan dua ratio yaitu ratio Debt to Equity dan rasio Non Halal Income terhadapa total income. Malaysia juga menggunakan model screening yang secara spesifik berlaku di negara tersebut yang dikeluarkan oleh Syariah Advisory Council (SAC) Bursa Malaysia. Dalam pendekatan mereka, untuk variable kualitatif mereka menggunakan standard yang hampir sama dengan di Indonesia, sedangkan variabel kuantitatif Malaysia menempatkan variabel Turnover dan Profit Before Tax sebesar 5\%, 10\%, 15\% dan 20\% berdasarkan pada segmen industrinya.

Sedangkan untuk negara Thailand, Filipina dan Thailand, mereka menggunakan model screening saham syariah yang berlaku secara umum di berbagai negara yaitu Dowjones, MSCI dan FTSE. Penggunaan model-model screening global memang banyak digunakan oleh negaranegara non-Muslim. Dalam model tersebut, terdapat dua tahapan yaitu kualitatif dan kuantitatif. Untuk screening kualitatif hampir sama, tetapi untuk variabel kuantitatif terdapat sedikit perbedaan dari proxy yang digunakan oleh masing-masing model.

Kedua, perbedaan model screening syariah menurut beberapa ahli keuangan syariah dipengaruhi oleh beberapa faktor. Pertama, perbedaan struktur masyarakat suatu negara di mana pasar saham syariah itu berada. Misalnya dalam hal ini adalah negara-negara yang memiliki basis penduduk mayoritas Islam akan menggunakan model screening yang khusus 
ljtihad, Jurnal Wacana Hukum Islam dan Kemanusiaan, Volume 16, No. 2, Desember 2016: 197-216

dan berlaku di negara tersebut. Alasan logisnya adalah, bahwa di negara tersebut memiliki ahli keuangan syariah yang banyak sehingga memungkinkan untuk membuat ijtihad sendiri tentang model yang akan berlaku di Negaranya. Kedua, adanya perbedaan industri keuangan yang ada pada negara tersebut akan mempengaruhi perbedaan model screening yangh ada. Sebagaimana kita ketahui bahwa screening saham syariah dilakukan untuk memastikan bahwa saham tersebut telah terbebas dari elemen yang haram. Namun demikian, dalam konteks bisnis seperti saat ini, maka tidak mungkin ada suatu kegiatan bisnis yang betul-betul terbebas dari kegiatan konvensional. Oleh karena itu, model screening bertujuan untuk meminimalkan dampak dari keuangan konvensional terhadap bisnis syariah. Atas dasar inilah maka perlu ditetapkan suatu standar yang bertujuan untuk meminimalkan dampak keuangan konvensional dalam model screening saham syariah.

Faktor ketiga adalah, adanya perbedaan mazhab yang di anut oleh sebagian besar ulama pada suatu negara merupakan salah satu faktor yang fundamental dalam penentuan model screening saham syariah d 5 Negara ASEAN. Menurut Derigz dan Marzban (2008) bahwa variable ini merupakan salah satu variabel yang sangat signifikan dalam mempengaruhi model screening saham syariah yang digunakan pada suatu pasar saham syariah.

Berdasarkan pada penelitian yang kami lakukan, maka ada beberapa rekomendasi yaitu; 1) Perlu dilakukan proses penyatuan atau paling tidak standarisasi model screening saham syariah di ASEAN khususnya dan di Dunia pada umumnya. Proses penyatuan ini tentu harus dimulai dengan proses penyatuan pemahaman dari para pembuat kebijakan di pasar modal syariah. Pada tahap selanjutnya para pembuat kebijakan dapat melakukan penyamaan variabel-variabel yang akan digunakan dalam proses seleksi saham apakah masuk kategori halal atau haram.

2) Kebijakan standarisasi saham syariah ini dapat dilakukan oleh dewan syariah bekerjasama dengan otoritas bursa saham syariah di beberapa negara ASEAN.

3) ASEAN Secretariat sebagai pihak yang berkepentingan dan bertanggungjawab dalam melakukan integrasi masyarakat ASEAN perlu membuat kebijakan strategis demi mendorong arah penyatuan model screening saham syariah di kawasan.

4) Dewan syariah dan ahli keuangan syariah di Negara ASEAN dapat melakukan musyawarah secara bersama untuk mencari model terbaik di pasar saham syariah. Selain 
Telaah kritis model screening saham syariah menuju Pasar Tunggal ASEAN (M. Ardiansyah, dkk.)

itu, hal ini tentu diharapka dapat mewujudkan saham syariah yang lebih tahan terhadap goncangan (financial shock) serta memiliki volatilitas yang lebih baik. Sehingga hal ini akan berdampak baik dalam meningkatkan kepercayaan masyarakat terhadap pasar saham syariah.

\section{Daftar pustaka}

Abdul Rahman, A., Yahya, M. A., and Mohd Nasir, M. H. "Islamic Norms for StockScreening a Comparison Between the Kuala Lumpur Stock Exchange Islamic Indexand the Dow Jones Islamic Market Index" dalam International Journal of Islamic and MiddleEastern Finance and Management, Vol. 3 No. 3, (2010): 228-240.

Al-Ghazali. Al-Mustashfa. Beirut: Dār al-Fikr, 1997.

Ardiansyah, Misnen and Abdul Qoyum, "Testing the Semi-strong Form Efficiency of Islamic Capital Market With Response to Information Content of DividendAnnouncement: A Study in Jakarta Islamic Index", dalam Journal of Modern Accounting and Auditing Vol. 8, No. 7,(2012): 1025-1041.

Derbel, Hatem, Bouraoui, Taoufik, \&Dammak, Neila. "Can IslamicFinanceConstitute a Solution to Crisis," dalam International Journal of Economics and Finance Vol. 3 No.3, (2011).

Derigs, Ulrich, andMarzban, Shehab. "Review and analysis of currentShariah-compliant equityscreening practices," dalam International Journal of Islamic and Middle Eastern Finance and Management, Vol. 1 No. 4, (2008): 285-303

Derigs, Ulrich, \& Marzban, Shehab. New strategies and a new paradigm for syariah-compliant portfolio optimization dalam Journal of Banking \& Finance, Vol. 33, (2009), pp. 11.

Dusuki, Asyraf Wajdi (ed.).Islamic Financial System; Principle and its Operation, Kuala Lumpur: ISRA Publication, 2012.

Dusuki, A. "Practice and Prospect of Islamic Real Estate Investment Trusts (IREITs) in Malaysian Islamic Capital Market", dalam Journal of Islamic Economics, Banking and Finance, Vol. 6, No. 2, (2011), 25-40

El-Ashkar, Ahmad Abdel Fattah. "Towards an Islamic Stock Exchange in aTransitional Stage.” Dalam Islamic Economic Studies Vol. 3 No.1 (1995): 79-112.1995

Fama, Eugene F., \& French, Kenneth R.’'Multifactor Explanations of Asset Pricing Anomalies,"dalam The Journal of Finance Vol. 51 (1), (1996).

Fatwa Dewan Syari'ah Nasional No: 40/DSN-MUI/X/2003 Tentang Pasar Modal dan Pedoman Umum Penerapan Prinsip Syariah di Bidang Pasar Modal 
ljtihad, Jurnal Wacana Hukum Islam dan Kemanusiaan, Volume 16, No. 2, Desember 2016: 197-216

Febrian, Erie, \&Herwany, Aldrin. "Volatility ForecastingModels and MarketCo-integration: A study on South-east Asian Markets,"dalam The Indonesia Capital Market Review Vol. 1 No. 1 (2009).

Febrian, Erie, \&Herwany, Aldrin. "The Performance of Asset Pricing Models Before, during, andafter Financial Crisis In Emerging Market: Evidence from Indonesia,"dalam The International Journal of Business and Finance Research Vol. 4 No. 1 (2010).

Guyot, Alexis.”Efficiency and Dynamics of Islamic Investment: Evidence of Geopolitical Effects on Dow Jones Islamic Market Indexes,"dalam Emerging Market Finance \& Trade Vol. 47 No. 6 ( 2012).

Herwany, Aldrin, \&Febrian, Erie. "Co-integration and Causality Analysis on DevelopedAsianMarket for Risk Management\&PortfolioSelection," dalam Gadjab Mada International Journal of Business Vol. 10 No.3 (2008).

Kamali, M.H., 1996. "Islamic Commercial Law: An Analysis of Futures" dalam The American Journal of Islamic Social Sciences, Vol. 13 No. 2 (1996): 197-224

Kassim, Salina H."'Global Financial Crisis of Islamic Stock Markets in Developed and Developing Countries," VRF Series, 2010.

Kassim, Salina H., "The Global Financial Crisis And The Integration Of Islamic Stock Markets In Developed And Developing Countries" dalam Asian Academy Of Management Journal Of Accounting And Finance, Vol. 9, No. 2 (2013): 75-94.

Majid, M.Shabri Abd. and Salina H.Kassim,"Potential Diversification Benefit Accross Global Islamic Equity Market" dalam Journal of Economics Cooperation and Development Vol.31 No. 4 ( 2010): 103-126.

Marzban, Shehab and Mohamed Donia, "Shariah-- compliant Equity Investments Frameworks,Trends andCrisis" dalam Harvar dIslamic Finance Forum Paper, (2010).

Mian, K. M., 'Shariah screening and islamic equity indexes', Islamic Finance: A PracticalGuide (2008): 25-39.

Omar, Moh. Azmi et.al.. Fundamental of Islamic Money Market and Islamic Capital Market, Wiley, Singapore; 2013.

Sani, N.A. and Othman, R. "Revision of Shariah Screening Methodology: The Status of Shariah-Compliant Companies in Malaysia" dalam Proceedings of the $3 \mathrm{rd}$ International Conferenceon Management (3rd ICM 2013), Malaysia, (2013): 51-63. 